Article

\title{
Plantation Development in the Turkana Basin: The Making of a New Desert?
}

\author{
Edward G. J. Stevenson
}

Department of Anthropology, University College London, London WC1H 0BW, UK; e.stevenson@ucl.ac.uk

Received: 30 November 2017; Accepted: 20 January 2018; Published: 25 January 2018

\begin{abstract}
Since the early 20th century, "desert reclamation" has been synonymous with large-scale waterworks and irrigation. These techniques have made it possible to produce abundant crops in arid or semi-arid environments. The costs have often been externalized, with increased environmental productivity in the new croplands counterbalanced by increased aridity elsewhere. In this paper I consider whose interests are served by such projects, and what kinds of social constructions of the natural and human environment make them possible. I focus on the Turkana basin, a watershed spanning the Ethiopian and Kenyan borders, where large dams and irrigation projects are currently being established with the goal of producing cash crops and hydro-electricity. In the narratives of the projects' proponents, the schemes are represented as part of a tradition of development stretching back to the American West. In the discourse of critics, the Aral Sea of Central Asia is frequently invoked. Considering Turkana in relation to these cases sheds light on the political and ecological gambits involved in desert reclamation, and helps us to understand the costs and benefits of such projects.
\end{abstract}

Keywords: desert reclamation; desertification; river basin development; political ecology; water

\section{Introduction}

In the late 1970s and early 1980s, in the wake of the Sahel drought, the concept of desertification gained wide currency. A key idea associated with desertification was that the practices of farmers and herders in the world's drylands were leading to rapid degradation of dryland ecosystems [1,2]. This narrative resonated with rising international concerns about the fragility of the natural environment, but the empirical basis for it was shaky. As Swift observes, "dry years (especially in the 1970s and early 1980s) were often compared with wet years (especially in the 1960s); this was then interpreted as a secular decline in productivity, rather than as a variation in the response of the natural vegetation or crops to soil moisture availability" [1] (p. 83). Nevertheless, the idea took hold, and was boosted by the endorsement of the UN Conference on Desertification (UNCOD) in 1978. The prescriptions for preventing desertification included large-scale afforestation and terracing projects, resettlement schemes, and promotion of alternative livelihoods. Such projects, led by governments and supported by international donors and non-government organizations, involved the mobilization of virtual armies, and absorbed vast amounts of capital. The short-term impacts on soil conservation were modest or even negative [3], and in some longitudinal studies of particular 'at-risk' landscapes, forest cover was observed to increase despite rises in population density (e.g., [4,5]).

Why did the desertification concept come to be so widely accepted? One answer is that the desertification narrative "met a need" and provided "a useful discourse" for powerful actors including governments, international agencies, and non-governmental organizations [1] (p. 84). Hoben characterized this discourse as a neo-Malthusian narrative of Africa as a "spoiled Eden", burdened by overpopulation, and in breach of carrying capacity - a situation remediable only through "massive investments in environmental reclamation" [6] (p. 11). The narrative appealed to influential groups who saw in it a way of extending their own power (cf. [7]). 
Inspired by the literature on desertification, in this paper I take a critical perspective on the phenomenon of 'desert reclamation', and investigate whose needs are served by this idea. In some ways desert reclamation is a mirror image of desertification: it represents a conviction that land degradation is not an inevitable process, but can be reversed through the application of proven techniques of resource management. In other ways, it closely resembles the desertification narrative. Just as desertification was used as a justification for large-scale projects that often had negative impacts for the livelihoods of rural people, so desert reclamation has led to manifestly inequitable outcomes. Since the early 20th century 'reclamation' has been synonymous with a particular set of techniques involving large-scale waterworks and irrigation. These techniques have made it possible to produce abundant crops in arid or semi-arid environments. But the costs of this model have often been 'externalized', in the economist's terms, with increased environmental productivity in the new croplands counterbalanced by increased aridity elsewhere. Given that the areas targeted for such schemes have usually been previously inhabited and worked by smallholder farmers or herders, their effects have also been to produce increased hunger and food insecurity.

I focus on the Omo-Turkana basin, a watershed spanning the Ethiopian and Kenyan borders, where large dams and irrigation projects are currently being established, with the goal of producing cash crops and hydro-electricity. Controversy clings to this project, and a highly polarized debate has emerged between proponents and critics. In the narratives of the projects' proponents, the schemes are represented as part of a tradition of economic development stretching back to the American West-large-scale interventions, such as the Hoover Dam, which are seen as yielding large benefits for national progress [8]. In the discourses of critics, on the other hand, the Aral Sea of Central Asia is frequently invoked as a reference point, and the inequitable distribution of costs and benefits between 'national' and local parties is emphasized (e.g., [9,10]). Despite the frequency with which these two comparison cases are mentioned, the similarities and differences between the Omo-Turkana situation and the American and Central Asian experiences have rarely received close attention. In what follows I consider the Omo-Turkana case in light of these two comparison cases, and ask what each suggests about the calculus of social and environmental planning around river basin engineering schemes. In particular, I consider the historical contexts in which these three interventions took place, and the narratives that accompanied them (see Table 1).

Table 1. Characteristics of the river basin case studies.

\begin{tabular}{cccccc}
\hline River Basin & Location $^{*}$ & Time Period & Area Irrigated (ha) $\mathbf{~}$ & Principal Crops & Reference \\
\hline Colorado & USA-Mexico & 1902-present & $2.4 \mathrm{~m}$ & alfalfa, wheat & {$[11]$} \\
Aral Sea & Central Asia & 1954-present & $7.5 \mathrm{~m}$ & cotton & {$[12]$} \\
Turkana & Ethiopia-Kenya & 2005-present & $175 \mathrm{k}$ & sugar & {$[13]$} \\
\hline
\end{tabular}

* The Aral Sea basin includes parts of Uzbekistan, Kazakhstan, Tajikistan, Kyrgyzstan, Afghanistan, and Turkmenistan. t Data are for circa 2000-2010 for the Colorado and circa 1988 for the Aral Sea basin. Data for the Turkana basin is the projection of the government of Ethiopia (Kuraz Sugar Development Project) (cf. [10]). In the lower Omo as of February 2016, sugar had been planted on approx. $11 \mathrm{kha}$, and an additional $13 \mathrm{kha}$ had been cleared [13]. (Units: $\mathrm{mha}=$ million hectares; $\mathrm{kha}=$ thousand hectares. .

One consideration that guides me in comparing these cases is the social construction of the natural environment that is implied in the planning process. Relevant questions include: Who is making claims to land and water? And whose prior claims are affected, or placed in jeopardy? One of the similarities that emerges from these comparisons is the location of significant hydrological engineering schemes on the borders or peripheries of states. The downstream impacts can be more easily ignored or written off if they occur 'over the border', beyond the planners' purview. The second consideration concerns historical and spatial scale. The degree to which ecosystems are improved or degraded by irrigation schemes can look very different depending on whether the question is considered on a small or large geographical scale, and over a short or long time horizon. At the time of writing, the Turkana basin schemes remain relatively small, and the major irrigation ventures there date back less than 
a decade. One of the advantages of comparison is to provide a longer timescale over which to consider the social and ecological processes involved.

\section{Dams and Development}

The scale and scope of dam-building and irrigation schemes in the 20th century is difficult to overstate. Between 1950 and 2000, on average, two large dams were built per day, with the number of large dams worldwide reaching approximately 45,000 by the end of the century $[14,15]$. Irrigation systems associated with large dams were first built by British colonists in Egypt in the late 19th century [16] and in the Sudan in the early 20th century [17]. In the wake of the Tennessee Valley Authority project, river-basin-wide systems of dams became a template for export after the Second World War, promoted by the Bretton Woods institutions and by European and American engineers and development advisors [18,19]. Post-independence governments in Africa, such as the administration of Kwame Nkrumah in Ghana, promoted dams as a centrepiece of national economic strategy [20]. In Ethiopia after the restitution of Haile Selassie by British forces, the government promoted a similar model, with the first river basin engineering scheme launched in the Awash Valley in the 1960s [21,22].

From the vantage point of the early 21st century, scholars can appraise the costs and benefits of this hydro-irrigation explosion. At a global level, there have been major benefits: an estimated $15 \%$ of food supply comes from land irrigated from large dams, and 19\% of electricity is generated by hydro-electric turbines [14]. However, planners have systematically understated the financial costs of large dams, which are, on average, almost twice as high as initially estimated [23]. When other kinds of losses are taken into account, e.g., farmland inundated by reservoirs, and reduced productivity of riverine and delta fisheries, the costs rise further. Social costs include the direct displacement of 40-80 m people [14], with at least $450 \mathrm{~m}$ more people affected by changes in river flows and environmental conditions [24]. These changes, the effects of which may be felt over multiple generations, erode people's sense of control over their lives, and undermine their psychosocial well-being $[25,26]$.

From a political ecology perspective, the social costs listed above might be counted as part of the attraction of hydro-electricity and irrigation projects. At the same time as they present an appearance of economic rationality and national advancement, mega-projects may function as projects of social engineering that place vital resources at the disposal of elites $[16,17]$. By undermining or sweeping away one socio-ecological order and replacing it with another, they present experts with the opportunity to redesign landscapes and impose new kinds of discipline on people and places they deem recalcitrant or unproductive. In the following section I introduce the landscape of the Turkana basin, and explore the processes that led to the construction of dams and plantations in the region.

\section{The Turkana Basin: Wetland, Dryland, or Desert?}

The Turkana Basin includes a wide range of ecosystems, from highland forests in southwest Ethiopia to drylands around Lake Turkana, the world's largest permanent desert lake. In terms of rainfall, the lower Omo (i.e., the area downstream of the River Mago) is semi-arid, with mean annual rainfall in the region of $250-500 \mathrm{~mm}$; Turkana County, Kenya, receives $<250 \mathrm{~mm}$ /year. But the geographical classification of this region must also take account of the river that runs through it, which includes riverine swamps, thick forests in the delta region, and (until recently) one of the most potentially productive fisheries on the continent [10]. In these terms, the Omo/Turkana region invites comparison with Africa's other great wetlands, including the Okavango and Zambezi [27].

The River Omo rises in Ethiopia's south-west highlands, fed by the rains that wash over the region each year, part of a great climate system that links the Indian Ocean and the Horn of Africa. The countless streams charged by these rains feed major rivers that in turn feed into the Omo [28]. The largest of them, the Gibe, is itself a major river. In its watershed rose the kingdoms and states of the Macha Oromo, which until the late 19th century constituted a political system independent of Ethiopia [29] — part of an archipelago of cities and states that marked precolonial Africa. Swelled by the Gibe, the Omo rolls through the territory of peoples speaking a dozen languages; in its lower 
course, the old river meanders and then fans out into a great inland delta before emptying into the salty waters of Lake Turkana. The flood of the Omo is the ecological pulse of the entire region, each seasonal inundation providing a cue to grow. For the aquatic life of the lake, it provides nutrients that prime the reproductive systems of fish to spawn [30]. For the people of the river's lower reaches-one of the most culturally and linguistically diverse regions of Africa-the flood, along with the appearance of the Pleiades in the night sky, marks the new year [31,32]. The flood is vital for their agro-pastoralist livelihoods [33].

The lower Omo was formally incorporated in Ethiopia through military campaigns under Emperor Menelik II in the late 19th century. After these campaigns, the southern marches, including the lower Omo, were economically important for highland Ethiopia, exploited for ivory and slaves, but remained politically peripheral to the Ethiopian state [34]. The principal impediment to settler colonialism was the semi-arid climate, which made the land unsuitable for plough agriculture as practiced by the highland Ethiopian colonists. The exceptions prove the rule: by the early 20th century, Maale and Ari-pockets of highlands where rainfall was higher-were readily incorporated into the system of tenant/serf farming and revenue extraction [35].

The first intensive farming operations in the lower Omo were attempted by North Korean state conglomerates in the early 1990s, in the last years of the military socialist Derg regime. Irrigation systems were installed to grow cotton, but a combination of unsuitable soils and salinity build-up led the venture to be abandoned. Nonetheless investors remained interested in the idea of plantation agriculture in the lower Omo, and soon after the takeover of power by the Ethiopian People's Revolutionary Democratic Front (EPRDF), plans to develop the Omo were drawn up. Woodroofe and Associates, under the auspices of the Government of Ethiopia and with external support from the African Development Bank, produced a 'Master Plan' for hydro-electricity generation and irrigated agriculture on the Omo in 1996 [36]. The scale of the designs that the state pursued on the Omo in the following years, however, was far greater than the Master Plan suggested.

The transformation of the basin began relatively modestly, with the construction of the Gilgel-Gibe I dam in the upper catchment of the basin (completed in 2004) and the Gilgel-Gibe II hydropower plant (completed in 2010). Gilgel-Gibe III (hereafter 'Gibe III') was a far greater undertaking. Two-hundred and forty meters high, and with an installed capacity of approximately 1870 Megawatts, it would more than double Ethiopia's electricity-generating capacity. Italian engineering firm Salini (which had previously built Gilgel-Gibe I and II) was handed the contract without open competition, and work on the dam began in 2006, before any environmental or social impact assessments (ESIAs) had been carried out. Unable to attain funding from other sources (the World Bank, the European Development Bank, or the African Development Bank declined their requests), the Ethiopian government eventually secured financing for the dam from the Chinese state. Although ESIAs were subsequently commissioned [37], they overlooked some of the most important potential impacts of the schemes, which would stem from the irrigation projects to be established in conjunction with the dam. The largest of them, the Kuraz Sugar Development Project, was projected to cover 175,000 ha [13].

In 2015, when the sluice gates of the Gibe III were closed and the reservoir behind the dam began to fill, conflicting predictions of the project's implications were afloat. Proponents of the dam and plantation schemes saw prosperity, urbanization: a desert reclaimed. Critics saw imminent ecological disaster and heightened economic marginalization for the people of the lower Omo and Lake Turkana. In the narratives of the project's proponents, Gibe III and Kuraz were sometimes explicitly, sometimes implicitly, placed as part of a tradition of economic development stretching back to the American West-large-scale interventions yielding large benefits for national progress [8,38]. The abundant waters of the lower catchment of the Omo, flowing south into Lake Turkana, were construed as a hydro-agricultural resource that demanded to be developed for the good of the nation. The narrative took the form: "This is how you (Europeans and Americans) got where you are. How dare you deny it to us?" In the discourse of the critics, the resources invested in the building of mega-dams-estimated at $€ 1.5 \mathrm{bn}$ for Gibe III [39] — would have been better spent on small-scale development projects that 
provided immediate benefits to local people, and gave them a say in planning their futures [40]. Critics also pointed to the incalculable environmental and biocultural costs of replacing a diverse landscape managed by indigenous stewards with commercial estates growing crops for export [41]. The narrative took the form: "Wherever this has been done, it has led to disaster." A recurring reference point was the Aral Sea (e.g., [9,10]).

In the following sections I review the cases of the Colorado and the Aral Sea and ask what each suggests about the calculus of social and ecological planning involved in hydro-agricultural projects. In the final part, I consider the shorter time series of evidence for ecological change in the Omo-Turkana since 2015, and identify common themes that emerge from consideration of the three case studies.

\section{The Colorado Basin}

"We have in the Colorado [River] an American Nile awaiting regulation, and it should be treated in as intelligent and vigorous a manner as the British government has treated its great Egyptian prototype."

Lippincott, 1912, cited by Worster [42] (p. 155)

Located in the American Southwest, and watered principally by snowmelt from the Rocky Mountains, the Colorado River runs through seven U.S. states, traversing the Sonoran Desert and northern Mexico, where the river historically terminated in a delta and emptied into the Gulf of California. It was in this region that high dams attained global prominence, and the damming and tapping of the Colorado is directly implicated in the rise of the economy of southern California and massive demographic growth in the U.S. Southwest since the mid-20th century. In recent years, with decreasing precipitation in the upper catchment, and increasing abstraction in the lower catchment of the Colorado, barely a drop of the river's water crosses the border to Mexico [43].

The story of the Colorado is crucial for understanding the history of desert reclamation-indeed, the term "reclamation" had its origin here, in the 1902 Reclamation Act by which the U.S. federal government mandated major works on the region's rivers in the interest of agricultural development and settlement of the West. This legislation, and the administrative apparatus that it spawned-including the Bureau of Reclamation, which went on to design and construct dams and irrigation systems across the region-was but one phase in a longer history of competition over natural resources, a drama played out among Native Americans, Mexicans, and descendants of European settlers, among others. In the reading of legal scholar Douglas J. Kenney, the "economic paradigm" that governed the usage of the Colorado from the nineteenth century onwards privileged the initiatives of European settlers over others, with Native Americans and Mexicans placed at the back of the queue for water rights [44]. In the Colorado Compact of 1944, $10 \%$ of the total annual flow of the Colorado (1.5 million acre feet, or approx. $2 \mathrm{~km}^{3}$ ) was allocated to Mexico, with the remaining $90 \%$ shared equally between the U.S. states of the upper and lower basin [45]. Over the course of the 20th century, large federal subsidies made possible the irrigation of millions of acres of land, supporting beef and dairy cattle, alfalfa, wheat, and (on a smaller scale, but much more profitably) fruit, nuts, and vegetables [11].

The development model devised by the Bureau of Reclamation involved the building of large dams that would serve the dual purpose of generating electricity and facilitating irrigation, with the high costs of dam building and irrigation works offset in part by electricity sales after the projects' completion [42]. The promise of irrigated land made available to settlers at bargain prices was supposed to lure white homesteaders from the more densely populated eastern states, and the Reclamation Act made provisions for this scenario by limiting the size of plots in its initial offer to 160 acres, and by instituting a requirement that owners should live on the land for at least five years [42]. In the event, few settlers took up the offer-in large part because of the hardship of living in a newly irrigated desert-while speculators acquired as much land as they could for resale. The largest beneficiaries of these projects were those who already had substantial capital, including established landowners 
whose property increased in value as a result of irrigation. Large landowners in the vicinity of cities such as Phoenix, Arizona, for example, benefitted from public funds spent on the Roosevelt Dam (completed in 1911), which provided increased water for their private estates [42]. The region's cities benefitted too, with increased quantities of water and electricity supporting rapid urban growth [46].

For the elites who came to control the majority of the new irrigated lands, a major challenge was obtaining enough workers to tend their estates. The solution they arrived at was to hire migrant workers, a majority of them Mexicans [42]. Meanwhile, as water abstractions for the expanding estates on the U.S. side of the border grew, the quality and quantity of water available for Mexico deteriorated. By the 1960s, high salinity rendered the water flowing into Mexico practically useless for agriculture. Mexican politicians complained that the U.S. government was in breach of the 1944 agreement $[42,47]$.

While Mexico had been allocated $10 \%$ of the river, and found itself with water that was too salty to use, the position of Native Americans in relation to the irrigation projects was more ambiguous. For most of the twentieth century, de facto exclusion of Native Americans from the profits accruing from industrial agriculture coexisted, albeit uneasily, with de jure rights of those living on reservations to "the water resources needed to sustain [their] new tribal homelands." As Kenney observes:

Translating this principle into actual water management in the Colorado River basin is an ongoing process, subject to considerable debate .... Arizona, in particular, features several tribes with Colorado River rights of great seniority, as these rights are defined as originating with the dates of the Indian treaties ... that typically took place before widespread homesteading by Anglos [descendants of European settlers]. [... ] By some estimates, large reservations such as the Navajo reservation in north-eastern Arizona-could conceivably by awarded the entire flow of the Colorado under this calculus. Politically this outcome is unacceptable to the non-Indians that would be displaced, so the 'solution' has been to withhold from tribes the financial resources needed to develop water projects until they agree to settlements that dramatically scale-back the size of their rights.

[44] (p. 132)

While Native Americans were effectively denied access to the benefits of the irrigation boom in the USA, those with the most attractive land and the greatest access to capital increasingly came to dominate, notably the agro-industrialists of Arizona and southern California [11,42]. Considering the basin as a whole, however, the highest price was paid by Mexicans. The logical end result of the economic paradigm - treating the river as a commodity-was to raise competition for water among the basin partners; but rather than competing on a level playing field, those upstream held a strong advantage. Since the 1960s, the Colorado River has rarely reached the sea. Its delta in Mexico disappeared, as did the forests and fisheries it used to support, and the riverine farms of the indigenous Cucapá people who lived there [15] (p. 29).

The drying-up of the Colorado delta roughly coincided with the emergence in the USA of an alternative paradigm that meaningfully challenges the economic paradigm, and highlights the human and environmental costs of river-basin development [44]. While communities seeking the removal of existing dams and the restitution of landscapes to their former states face strong opposition, some of these campaigns have paid off. The success stories include California's Echo Park (site of the first environmental preservation campaign in U.S. history) and Mono Lake [48]. As the region's ageing stock of dams is increasingly threatened by reservoir sedimentation, more dams are being decommissioned than are being built in the USA [15] (p. 1xi). Judging from the experience with the Colorado, the timescale of a hydraulic civilization's rise to maturity and possible decline would appear to be roughly a century.

The experience of the Aral Sea, however, suggests it may be shorter still. 


\section{The Aral Sea}

The Aral Sea was in the early twentieth century the world's fourth-largest inland water body. Located on the borders of the Central Asian states of Kazakhstan and Uzbekistan, it was for most of the 20th century part of the Soviet Union, with economic and political control exercised from Moscow. Beginning in the late 1950s, large-scale irrigation works serving cotton estates led to major abstractions from the principal rivers that fed the Aral Sea, the Amu Dar'ya and Syr Dar'ya, which have their sources in the snow and glaciers of the Pamir and Tian Shan mountain ranges [49]. The construction of major canals diverting water from these rivers, and concurrent increases in land area devoted to cotton in the 1970s and 1980s led to the complete drying up of the Amu Dar'ya and occasional drying up of the Syr Dar'ya. As a consequence of the reduced inflow, the depth and surface area of the Aral Sea declined precipitously, and split into two or more bodies of water. Exposed areas of former lake bed turned to salt pans; the maritime climate of the region turned dryer; biodiversity plummeted. Endemic fish species, such as the Aral salmon, became extinct, and by the early 2000s scientists surveying terrestrial biodiversity reported fewer than half of the species of mammals and birds previously observed [50].

The negative impacts of the disappearance of the sea were felt most of all by the people who had formerly lived along its shores, especially the Karakalpak fishers and herders of Uzbekistan. Fisheries that once sustained one of the Soviet Union's largest fish-processing factories were destroyed; grazing lands dried out; and entire communities were marooned as navigation routes between coastal towns and villages were lost. Initially Karakalpakstan shared in the wealth produced by the new schemes, growing cotton, rice, wheat, and vegetables with irrigation infrastructure. But being situated at the end of the line in terms of access to the irrigation system meant that the water they received grew increasingly saline. Production peaked in the 1980s and has since been in decline, with increasing volumes of water required to flush previously accumulated salt out of the soil [51].

Other effects were felt further afield. Windblown salt and dust from the desiccated lake bed had negative effects on agriculture in a wide zone downwind of the basin. Impacts on human health (in addition to those experienced via loss of employment in the fishery and transport sectors) included respiratory infections exacerbated by windblown salts, as well as an increased incidence of cancers and other conditions potentially related to exposure to the heavy metals and pesticides associated with industrial farming operations [52].

Although the most critical phases of the Aral Sea disaster played out in the later years of the Soviet Union, relations between Muscovite planners and the region can be traced to the conquest of Central Asia by imperial Russia in the 19th century. Economically important first as a source of furs, and later for its mineral wealth, the relationship between the eastern and western parts of the empire was long characterized by extraction. In the vision of modernist planners, this frontier region "was to be reclaimed from wilderness with the help of modern technology and railroads, colonized and transformed from a cold and unwelcoming wasteland roamed by backward savages into a populous and prosperous part of Russia itself" [53] (p. 282). The historical experience of the Aral Sea region renders this civilizing narrative bitterly ironic, as-far from reclaiming the region from "wilderness" - the very projects that were projected to bring wealth and civilization produced in their turn a new and distinctive kind of desert.

\section{Discussion: Omo and Lake Turkana Revisited}

When any given large dam or irrigation project is launched, it is often claimed that it is too early to say how productive or destructive the transformed landscape of the basin will be. The value of historical comparison is that it helps us consider probable trajectories of change, and, in light of them, to think anew about the possibilities for course correction or mitigation of harms. In the literature on river basin development, two types of historical comparison are commonly made: country- or region-specific comparisons (e.g., [22]); and global surveys that attempt to discern modal patterns in terms of the contributions of large hydro-irrigation projects to development (e.g., [14,23,24]). In this 
article I have taken a different approach, focusing not on the experience of a single world area, nor on global patterns, but on those comparison cases that recur most frequently in the rhetoric of proponents and critics.

What can we glean from these two cases that is of relevance to Turkana? In both cases, two narratives can be discerned: a heroic narrative of feats of engineering and a tragic narrative of desiccation (the Colorado as "a river no more" [44]; the Aral Sea as a cartographic error). In the case of the Colorado, it is the heroic story-accompanied by a myth of equitably shared benefits-that prevails; in the case of the Aral Sea, it is the tragic one. But despite the rhetorical uses to which they have been put, the experiences of the Colorado basin and the Aral Sea are in many ways similar. The similarities include the conceptual importance of regional or international boundaries for externalizing ecological costs, and the ethnic "othering" or simple erasure of the people whose lands and livelihoods were affected by the rerouting or repurposing of rivers. The existence of political boundaries and gradients of power facilitate what Steve Rayner calls "institutionalized forgetfulness" [54] (p. 110): they help to hold at bay knowledge that would otherwise be problematic for the achievement of institutional objectives.

Since the Gibe III reservoir began filling in 2015, the shoreline at Ferguson's Gulf, the most productive fishery on the lake, has receded by $1.5 \mathrm{~km}$ [55]. Abstraction of increasing quantities of water for irrigation upstream would cause the lake levels to drop further, potentially splitting into two or more smaller lakes, like the Aral Sea [10]. Indeed, even if irrigation were suspended, fisheries biologists predict that the regulation of the river by Gibe III will lower fish yields from Lake Turkana by more than two-thirds, since the lake's fish depend on the seasonal flood pulse (the nutrients and fresh water that the Omo delivers) as a cue for breeding [30]. This is "uncomfortable knowledge," in Rayner's terms, and those whose interests are served by the Gibe III dam and Omo plantations can be expected to deny it [54]. So far, the Kenyan government has not forced its Ethiopian counterpart to acknowledge the threats these developments pose for those whose livelihoods depend on the lake. Despite attempts by the United Nations Environment Programme to broker an agreement between the governments, the key problem of water-sharing remains unresolved [55-57].

And what of the people of the lower Omo valley? For centuries they have relied on a three-pillar strategy to make a living in the semi-arid climate: combining herding, farming on rain-fed land, and farming on land inundated by the annual rise of the river [58]. The river flood, since it carried water from a large catchment in highland Ethiopia, dependably provided the water and silt needed for farming. With the Gibe III dam, the flood has ended, and the people of the lower Omo are therefore deprived of one crucial component of their livelihood. Some of the most valuable agricultural lands have been annexed by the expanding sugar plantations, and the availability of vital fall-back resources, in the form of game animals and wild foods, is severely constrained, as scrubland has been razed for plantation development [59]. At the same time as thousands of new settlers and migrant labourers converge on the plantations of the lower Omo, a food insecurity crisis looms for the region's indigenous people [60]. The safety net provided by the Ethiopian government in the form of a "villagization" programme has been woefully inadequate [61]. To avert famine, there is a need for a comprehensive and well-funded livelihood reconstruction programme [62].

In most scholarly work and media reports on this unfolding crisis, the voices and opinions of the people of the lower Omo and Turkana have been conspicuously absent. Ironically, the most prominent opponents of the Omo dam and irrigation schemes-advocacy groups such as International Rivers and the Oakland Institute-are based not in Africa but in the western USA. But there is a logic in this. The region of the world with the longest history of massive hydraulic engineering has given birth to some of its most forceful critics. If there is one common denominator in the history of large dam and irrigation schemes, it is the unfair distribution of costs and benefits. The people of the American West have certainly not benefitted equally from the experiments carried out on the region's rivers, any more than the peoples of the Soviet Union or Central Asia benefitted equally from the sacrifice of the Aral Sea. The critics' refrain — "Wherever this has been tried, it has been a disaster" - might be amended: Wherever this has been tried, it has benefitted some at the expense of others. 
Acknowledgments: I have benefitted from conversations with Jennifer Hodbod, Benedikt Kamski, Dan Mains, Ruth Mandel, Selam Shiferaw, David Turton, and members of the Omo-Turkana Research Network. I am grateful to Troy Sternberg and Ariell Ahearn for their invitation to present some of the ideas in this paper at the Oxford Desert Conference, in June 2017. Errors that remain are my own.

Conflicts of Interest: The author declares no conflict of interest.

\section{References}

1. Swift, J. Desertification: Narratives, winners and losers. In The Lie of the Land: Challenging Received Wisdom on the African Environment; Leach, M., Mearns, R., Eds.; International African Institute/James Currey: Oxford, UK, 1996; pp. 73-90.

2. Mortimore, M. Roots in the African Dust: Sustaining the Sub-Saharan Drylands; Cambridge University Press: Cambridge, UK; New York, NY, USA, 1998.

3. Herweg, K.; Ludi, E. The performance of selected soil and water conservation measures-Case studies from Ethiopia and Eritrea. CATENA 1999, 36, 99-114. [CrossRef]

4. Nyssen, J.; Haile, M.; Naudts, J.; Munro, N.; Poesen, J.; Moeyersons, J.; Frankl, A.; Deckers, J.; Pankhurst, R. Desertification? Northern Ethiopia re-photographed after 140 years. Sci. Total Environ. 2009, 407, 2749-2755. [CrossRef] [PubMed]

5. Tiffen, M.; Mortimore, M.; Gichuki, F. More People, Less Erosion: Environmental Recovery in Kenya; Wiley-Blackwell: Chichester, UK; New York, NY, USA, 1993.

6. Hoben, A. Paradigms and politics: The cultural construction of environmental policy in Ethiopia. World Dev. 1995, 23, 1007-1021. [CrossRef]

7. Ferguson, J. The Anti-Politics Machine: Development, Depoliticization, and Bureaucratic Power in Lesotho. University of Minnesota Press: Minneapolis, MN, USA, 1994.

8. Pottinger, L. A Tale of Two Dams: Comparing Ethiopia's Grand Renaissance to Hoover. International Rivers Blog. Post date: 9 July 2013. Available online: https:/ / www.internationalrivers.org/blogs/229/a-tale-oftwo-dams-comparing-ethiopia\%E2\%80\%99s-grand-renaissance-to-hoover (accessed on 20 November 2017).

9. International Rivers. The Downstream Impacts of Ethiopia's Gibe III Dam: East Africa's "Aral Sea" in the Making? International Rivers: Berkeley, CA, USA, 2013. Available online: https:/ /www.internationalrivers.org/ resources/gibe-iii-s-impacts-on-lake-turkana-7773 (accessed on 20 November 2017).

10. Avery, S. What Future for Lake Turkana? The Impact of Hydropower and Irrigation on the World's Largest Desert Lake; African Studies Center, University of Oxford: Oxford, UK, 2013. Available online: http:/ / www.africanstudies.ox.ac.uk/lake-turkana-and-lower-omo-hydrological-impacts-majordam-and-irrigation-developments (accessed on 20 November 2017).

11. Cohen, M.; Christian-Smith, J.; Berggren, J. Water to Supply the Land: Irrigated Agriculture in the Colorado River Basin; Pacific Institute: Oakland, CA, USA, 2013.

12. Saiko, T.A.; Zonn, I.S. Irrigation expansion and dynamics of desertification in the Circum-Aral region of Central Asia. Appl. Geogr. 2000, 20, 349-367. [CrossRef]

13. Kamski, B. The Kuraz Sugar Development Project (KSDP) in Ethiopia: Between 'sweet visions' and mounting challenges. J. East. Afr. Stud. 2016, 10, 568-580. [CrossRef]

14. World Commission on Dams. Dams and Development: A New Framework for Decision-Making; Earthscan: London, UK, 2000.

15. McCully, P. Silenced Rivers: The Ecology and Politics of Large Dams; Enlarged \& Updated Edition; Zed Books: London, UK, 2001.

16. Mitchell, T. Rule of Experts: Egypt, Techno-Politics, Modernity; University of California Press: Berkeley, CA, USA, 2002.

17. Bernal, V. Colonial Moral Economy and the Discipline of Development: The Gezira Scheme and "Modern" Sudan. Cult. Anthropol. 1997, 12, 447-479. [CrossRef]

18. Sneddon, C. Concrete Revolution: Large Dams, Cold War Geopolitics, and the US Bureau of Reclamation; University of Chicago Press: Chicago, IL, USA, 2015.

19. Sneddon, C.; Fox, C. The Cold War, the US Bureau of Reclamation, and the technopolitics of river basin development, 1950-1970. Political Geogr. 2011, 30, 450-460. [CrossRef] 
20. Miescher, S.F. “Nkrumah's Baby”: The Akosombo Dam and the dream of development in Ghana, 1952-1966. Water History 2014, 6, 1-26. [CrossRef]

21. Kloos, H. Development, drought, and famine in the Awash Valley of Ethiopia. Afr. Stud. Rev. 1982, 25, 21-48. [CrossRef]

22. Kloos, H.; Legesse, W.; McFeeters, S.K.; Turton, D. Problems for pastoralists in the lowlands: River basin development in the Awash and Omo valleys. In Water Resources Management in Ethiopia: Implications for the Nile Basin; Kloos, H., Legesse, W., Eds.; Cambria Press: New York, NY, USA, 2010.

23. Ansar, A.; Flyvbjerg, B.; Budzier, A.; Lunn, D. Should we build more large dams? The actual costs of hydropower megaproject development. Energy Policy 2014, 69, 43-56. [CrossRef]

24. Richter, B.; Sandra, P.; Carmen, R.; Thayer, S.; Bernhard, L.; Allegra, C.; Morgan, C. Lost in Development's Shadow: The Downstream Human Consequences of Dams. Water Altern. 2010, 3, 14-42.

25. Colson, E. The Social Consequences of Resettlement; Manchester University Press: Manchester, UK, 1971.

26. Scudder, T. The Future of Large Dams: Dealing with Social, Environmental, Institutional, and Political Costs; Routledge: London, UK, 2006.

27. Adams, W.M. Wasting the Rain: Rivers, People and Planning in Africa; University of Minnesota Press: Minneapolis, MN, USA, 1992.

28. Butzer, K.W. The Recent History of an Ethiopia Delta: The Omo River and the Level of Lake Rudolf; University of Chicago Press: Chicago, IL, USA, 1971.

29. Hassen, M. The Oromo of Ethiopia: A History, 1570-1860; Red Sea Press: Trenton, NJ, USA, 1994.

30. Gownaris, N.J.; Pikitch, E.K.; Aller, J.Y.; Kaufman, L.S.; Kolding, J.; Lwiza, K.M.M.; Obiero, K.O.; Ojwang, W.O.; Malala, J.O.; Rountos, K.J. Fisheries and water level fluctuations in the world's largest desert lake. Ecohydrology 2017, 10, e1769. [CrossRef]

31. Girke, F. Homeland, Boundary, Resource: The Collision of Place-Making Projects on the Lower Omo River, Ethiopia; Working Papers/Max-Planck-Institute for Social Anthropology No. 148; Max Planck Institute for Social Anthropology: Halle/Saale, Germany, 2013.

32. Ruggles, C.L.N. (Ed.) Mursi and Borana Calendars. In Handbook of Archaeoastronomy and Ethnoastronomy; Springer: New York, NY, USA, 2015; pp. 1041-1050. [CrossRef]

33. Turton, D. The Downstream Impact. In Proceedings of the Gibe III Dam, School of Oriental and African Studies (SOAS), London, UK, 10 November 2010. Available online: http://www.mursi.org/pdf/RAS\% 20Talk\%20-\%20Copy.pdf/view (accessed on 20 November 2017).

34. Donham, D.L.; James, W. (Eds.) The Southern Marches of Imperial Ethiopia: Essays in History and Social Anthropology; Cambridge University Press: Cambridge, UK, 1986.

35. Donham, D.L. Old Abyssinia and the new Ethiopian empire: Themes in social history. In The Southern Marches of Imperial Ethiopia: Essays in History and Social Anthropology; Cambridge University Press: Cambridge, UK, 1986; pp. 3-50.

36. Woodroofe, R. Omo-Gibe River Basin Development Master Plan Study: Final Draft Report; Federal Democratic Republic of Ethiopia, Ministry of Water Resources: Addis Ababa, Ethiopia, 1996.

37. Agriconsulting S.p.A.; Mid-Day International. Gibe III Hydroelectric Project: Environmental and Social Impact Assessment. Additional Study on Downstream Impact; Electric Power Corporation: Addis Ababa, Ethiopian, 2009.

38. Tadesse, K. Ethiopia: Big Nile Dam Could Ease Africa Power Failures. Christian Science Monitor. Available online: https:/ /www.csmonitor.com/Environment/Latest-News-Wires/2013/0703/Ethiopia-Big-Niledam-could-ease-Africa-power-failures (accessed on 3 July 2013).

39. Salini Impregilo. Ethiopia Inaugurates Tallest RCC Dam in World Built by Salini Impregilo. Press Release. Available online: http:/ / www.salini-impregilo.com (accessed on 17 December 2016).

40. Fong, C. The Scramble for Water, Land, and Oil in the Lower Omo Valley; International Rivers: Berkeley, CA, USA, 2015.

41. Survival International. Progress Can Kill: How Imposed Development Destroys the Health of Tribal Peoples; Survival International: London, UK, 2007.

42. Worster, D. Rivers of Empire: Water, Aridity, and the Growth of the American West; Oxford University Press: Oxford, UK, 1985. 
43. Owen, D. Where the River Runs Dry: The Colorado and America's Water Crisis. The New Yorker. Available online: http:/ / www.newyorker.com/magazine/2015/05/25/the-disappearing-river (accessed on 25 May 2015).

44. Kenney, D.J. The Colorado River: What prospect for "a river no more"? In River Basin Trajectories: Societies, Environments and Development; Molle, F., Wester, P., Eds.; CABI: Wallingford, UK, 2009; pp. 123-146.

45. Hundley, N. Water and the West: The Colorado River Compact and the Politics of Water in the American West; University of California Press: Berkeley, CA, USA, 1975.

46. Reisner, M. Cadillac Desert: The American West and Its Disappearing Water (Revised); Penguin: London, UK, 1993.

47. Brownell, H.; Eaton, S.D. The Colorado River salinity problem with Mexico. Am. J. Int. Law 1975, 69, $255-269$. [CrossRef]

48. Horowitz, H. Aral sea analogs in the American West. In Disaster by Design: The Aral Sea and Its Lessons for Sustainability; Edelstein, M.R., Cerny, A., Gadaev, A., Eds.; Emerald: Bingley, UK, 2012; pp. 89-103.

49. Vostokova, E.A. Ecological disaster linked to landscape composition changes in the Aral Sea basin. In Creeping Environmental Problems and Sustainable Development in the Aral Sea Basin; Glantz, M., Ed.; Cambridge University Press: Cambridge, UK; New York, NY, USA, 1999; pp. 26-46.

50. Micklin, P. The Aral Sea Disaster. Annu. Rev. Earth Planet. Sci. 2007, 35, 47-72. [CrossRef]

51. Pearce, F. When the Rivers Run Dry; Transworld: London, UK, 2006.

52. O'Hara, S.L.; Wiggs, G.F.; Mamedov, B.; Davidson, G.; Hubbard, R.B. Exposure to airborne dust contaminated with pesticide in the Aral Sea region. Lancet 2000, 355, 627-628. [CrossRef]

53. Glebov, S. Siberian ruptures: Dilemmas of ethnography in an imperial situation. In An Empire of Others: Making Ethnographic Knowledge in Imperial Russia and the USSR; Cvetkovski, R., Hofmeister, A., Eds.; Central European University Press: Budapest, Hungary, 2013; pp. 281-310.

54. Rayner, S. Uncomfortable knowledge: The social construction of ignorance in science and environmental policy discourses. Econ. Soc. 2012, 41, 107-125. [CrossRef]

55. Mutambo, A. Ethiopia Denies Forcing through Gibe Dams Project. Daily Nation (Newspaper); Kenya. Available online: http://www.nation.co.ke/news/Gibe-Dams-project-on-Kenya-and-Ethiopia/10563816882-10d7oky/index.html (accessed on 17 February 2017).

56. Arnold, D. Kenya, Ethiopia Mediating Omo River Water Controversy. Voice of America (News Agency), USA. Available online: https: / www.voanews.com/a/kenya-ethiopia-mediating-omo-river-water-controversy / 1770973.html (accessed on 16 October 2013).

57. Human Rights Watch. Ethiopia: Dams, Plantations a Threat to Kenyans. 2017. Available online: https://www.hrw.org/news/2017/02/14/ethiopia-dams-plantations-threat-kenyans (accessed on 20 November 2017).

58. Turton, D. Mursi Response to Drought: Some Lessons for Relief and Rehabilitation. Afr. Aff. 1985, 84, 331-346. [CrossRef]

59. Buffavand, L. 'The land does not like them': Contesting dispossession in cosmological terms in Mela, south-west Ethiopia. J. East. Afr. Stud. 2016, 10, 476-493. [CrossRef]

60. Carr, C.J. River Basin Development and Human Rights in Eastern Africa: A Policy Crossroads; Springer: Cham, Switzerland, 2017.

61. Stevenson, E.G.J.; Buffavand, L. 'Do our bodies know their ways?' Villagization, food insecurity, and ill-being in Ethiopia's Lower Omo valley. Afr. Stud. Rev. 2018, in press.

62. Turton, D. Hydropower and irrigation development in the Omo valley: Development for whom? In Proceedings of the International Conference on Ethiopian Studies, Warsaw, Poland, 28 August 2015.

(c) 2018 by the author. Licensee MDPI, Basel, Switzerland. This article is an open access article distributed under the terms and conditions of the Creative Commons Attribution (CC BY) license (http:// creativecommons.org/licenses/by/4.0/). 